\title{
Peningkatan keyakinan diri dan hasil belajar guling depan melalui latihan imagery
}

\author{
Rizki Sito Harimurti \\ Madrasah Aliyah (MA) Sunan Pandanaran. Jl. Kaliurang Km. 12,5 Sleman Yogyakarta, Indonesia \\ Corresponding Author. Email: sitoha@gmail.com
}

Received: 21 July 2016; Revised: 6 September 2018; Accepted: 17 September 2018

\begin{abstract}
Abstrak
Penelitian ini bertujuan untuk meningkatkan keyakinan diri dan hasil belajar guling depan pada siswa putri kelas X Madrasah Aliyah Sunan Pandanaran melalui integrasi latihan imagery pada pembelajaran Penjasorkes. Penelitian ini merupakan penelitian tindakan kelas (PTK) yang dilaksanakan dalam dua siklus. Setiap siklus terdiri empat tahapan yaitu: persiapan, pelaksanaan, observasi, dan refleksi. Analisis hasil penelitian dilakukan secara deskriptif kualitatif. Subjek penelitian ini adalah 25 siswa dari kelas X A Madrasah Aliyah Sunan Pandanaran. Tindakan yang dilakukan berupa integrasi latihan imagery dalam pembelajaran guling depan. Pengambilan data penelitian melalui tes unjuk kerja, observasi, dan angket skala keyakinan diri. Tes unjuk kerja dilakukan pada penilaian hasil belajar guling depan. Angket skala keyakinan diri untuk mengukur tingkat keyakinan diri siswa. Sedangkan observasi dilakukan selama pembelajaran berlangsung untuk mengetahui keterlaksanaan pembelajaran. Hasil penelitian menunjukkan bahwa melalui program latihan imagery yang diintegrasikan dalam pembelajaran, siswa mengalami peningkatan keyakinan diri dan hasil belajar pada materi guling depan.
\end{abstract}

Kata Kunci: keyakinan diri, guling depan, imagery

\section{Improve self-efficacy and learning outcomes of the forward roll through the exercise imagery}

\begin{abstract}
This research aims to improve self-efficacy and learning outcomes in the forward roll of female students of class X Madrasah Aliyah Sunan Pandanaran through the integration of imagery exercise in teaching Physical Education. This research is a classroom action research (CAR) conducted in two cycles. Each cycle comprised four stages: preparation, execution, observation, and reflection. The analysis of the results of research was conducted by qualitative descriptive manner. The subjects were 25 students of class X A, Madrasah Aliyah Sunan Pandanaran. The actions taken were in the form of imagery exercise integration into forward roll teaching. The collecting of the research data was through performance tests, observation, and self-efficacy scale questionnaire. The results show that through the imagery exercise program that is integrated into the lesson, students' self-efficacy and learning outcome increase.
\end{abstract}

Keywords: self-efficacy, forward roll, imagery

How to Cite: Harimurti, R. (2018). Peningkatan keyakinan diri dan hasil belajar guling depan melalui latihan imagery. Jurnal Keolahragaan, 6(1), 87-99. doi:http://dx.doi.org/10.21831/jk.v6i1.10097

http://dx.doi.org/10.21831/jk.v6i1.10097

\section{PENDAHULUAN}

Pada tahun ajaran 2015/2016 Madrasah Aliyah Sunan Pandanaran menyusun silabus sebagai landasan dalam menyelenggarakan pembelajaran selama satu tahun ajaran. Adapun dalam silabis pada mata pelajaran pendidikan jasmani, salah satu materi yang harus disampai- kan adalah senam lantai tanpa alat. Selanjutnya, untuk mengetahui materi yang akan diajarkan guru perlu merujuk pada buku paket sebagai sumber mengajar. Hal ini dirasa penting karena dalam silabus, materi yang harus dipelajari dalam senam lantai tanpa alat tidak disebutkan lebih spesifik lagi. Adapun sebagaimana yang ada pada 
buku paket, jenjang kelas $\mathrm{X}$ mata pelajaran pendidikan jasmani materi yang harus disampaikan kepada siswa pada bagian senam lantai tanpa alat adalah materi guling depan. Dengan demikian, guru pendidikan jasmani yang mengajar kelas $\mathrm{X}$ diharapkan dapat menyampaikan materi guling depan.

Fakta yang terjadi di Madrasah Aliyah Sunan Pandanaran, dalam pembelajaran penjasorkes guru mengalami kendala dalam mengajar materi guling depan. Pada awalnya guru tidak menyangka akan mengalami kesulitan dalam menyampaikan materi guling depan. Hal ini karena latar belakang materi guling depan merupakan materi senam lantai yang tergolong teknik sederhana dan dipelajari pada jenjang sekolah dasar, seharusnya siswa kelas X sudah terampil melakukan gerakan guling depan. Namun yang terjadi di lapangan tidak sama seperti yang seharusnya. Hasil pengamatan yang diperoleh menunjukkan bahwa siswa kela X putri di Madrasah Aliyah Sunan Pandanaran memiliki keterampilan yang rendah dalam melakukan guling depan. Selanjutnya, dari hasil pengamatan diketahui pula bahwa faktor yang menyebabkan pembelajaran guling depan berjalan tidak maksimal adalah rendahnya keyakinan diri yang dimiliki siswa.

Sementara itu, Zimmerman, Bandura, \& Martinez-Pons, (1992, p.663) mengutarakan, Students' beliefs in their efficacy for selfregulated learning affected their perceived selfefficacy for academic achievement, which in turn influenced the academic goals they set for themselves and their final academic achievement. Keyakinan diri sebaiknya dimiliki siswa selama proses belajar karena akan berpengaruh terhadap hasil belajar. Pendapat ini dikuatkan oleh Zimmerman (2000, p.82) yang mengatakan bahwa selama dua dekade terakhir, keyakinan diri telah muncul sebagai prediktor yang sangat efektif motivasi dan belajar siswa. Dengan demikian, meningkatkan keyakinan diri pada siswa merupakan hal yang perlu dilakukan untuk menyelenggarakan pembelajaran guling depan yang efektif.

Keterampilan guling depan harus dikuasai siswa karena berhubungan dengan teknik gerakan senam lantai yang lain yang lebih sulit. Gerakan senam lantai yang berkaitan dengan gerakan guling depan diantaranya adalah guling lenting dan loncat harimau. Hal ini sesuai dengan yang disampaikan Menteri Negara Pemuda dan Olahraga (2008, p.19) pada buku bertajuk Cerdas dan Bugar Dengan Senam Lantai bahwa sebelum belajar gerakan yang sulit, siswa hendaknya terlebih dahulu menguasai gerakan yang lebih mudah. Oleh sebab itu, gerakan guling lenting dan loncat harimau bisa dipelajari jika siswa terampil melakukan gerakan guling depan.

Salah satu usaha yang dapat dilakukan adalah dengan melakukan improvisasi pada pembelajaran. Improvisasi yang dilakukan adalah dengan mengintegrasikan latihan imagery dalam menyampaikan materi guling depan. Berbagai terori menyatakan bahwa imagery dapat membantu seseorang untuk menguasai suatu keterampilan gerak tertentu. Sebagaimana hasil penelitian Ay, Halawaweh, dan Al-Taieb (2013, p.227), ... the combination of mental movement imagery and physical practiceenhanced learning can improved motor skill performance. Hasil penelitian tersebut menguatkan teori bahwa imagery bermanfaat bagi individu yang sedang mempelajari gerak tertentu.

Selanjutnya Giacobbi, Tuccitto, \& Buman (2010, p.492) mengemukakan bahwa imagery dapat meningkatkan keyakinan diri seseorang untuk melakukan suatu gerakan tertentu. Sementara itu, keyakinan diri yang tinggi sebaiknya dimiliki siswa dalam belajar guling depan. Sebagaimana McAuley (1985, p.283) yang mengatakan bahwa hasil penelitiannya menunjukkan bahwa keyakinan diri berpengaruh terhadap keberhasilan individu melakukan keterampilan motorik. Pendapat ini juga dikuatkan oleh Destani (2011, pp.193-194) dalam disertasinya yang mengatakan bahwa meski masih dibutuhkan penelitian lebih lanjut, hasil penelitian yang telah dilakukan mampu membuktikan bahwa keyakinan diri dapat mengoptimalkan aktifitas fisik. Oleh sebab itu, imagery dirasa sangat perlu diintegrasikan dalam pembelajaran untuk membantu siswa dalam belajar dan menguasai keterampilan guling depan.

Pada penelitian ini permasalahan dibatasi pada integrasi latihan imagery pada pembelajaran pendidikan jasmani untuk meningkatkan keyakinan diri dan hasil belajar guling depan siswa putri kelas X Madrasah Aliyah Sunan Pandanaran. Dari identifikasi masalah yang ada, maka dapat disusun rumusan masalah yaitu, "Apakah integrasi latihan imagery dalam pembelajaran penjasorkes dapat meningkatkan keyakinan diri dan hasil belajar guling depan pada siswa putri kelas X Madrasah Aliyah Sunan Pandanaran?"

Adapun tujuan dari penelitian ini adalah untuk meningkatkan keyakinan diri dan hasil belajar guling depan pada siswa putri kelas $\mathrm{X}$ Madrasah Aliyah Sunan Pandanaran. Secara teoritis, penelitian ini diharapkan bermanfaat untuk dunia pendidikan utamanya menghasilkan 
desain pembelajaran yang dapat meningkatkan keyakinan diri dan hasil belajar guling depan. Selain itu, penelitian ini diharapkan dapat menambah pengetahuan bagi peneliti maupun bagi pembaca. Adapun secara praktis, hasil penelitian yang diperoleh diharapkan berguna bagi siswa maupun guru. Bagi siswa, diharapkan dapat bermanfaat dalam membentuk keyakinan diri dan memeroleh hasil belajar yang tinggi pada materi guling depan. Bagi guru, diharapkan dapat memberikan pengalaman dan pengetahuan sehingga mampu menyelenggarakan pembelajaran yang dapat meningkatkan keyakinan diri dan hasil belajar siswa pada materi guling depan.

\section{Keyakinan Diri}

Sebagaimana yang disampaikan Bandura (1999, p.203), "Perceived academic self-efficacy is defined as personal judgments of one's capabilities to organize and execute courses of action to attain designated types of educational performances." Dari pernyataan itu dapat diketahui bahwa para akademisi mendefinisikan keyakinan diri sebagai penilaian diri terhadap suatu kemampuan untuk mengorganisir dan melakukan keterampilan yang sedang dipelajari. Adapun Gao, Lee, \& Harrison (2012, p.239) mengatakan, "Self-efficacy is beliefs about one's capabilities to learn or perform behaviors at designated levels, and outcome expectancy refers to a person's beliefs concerning the likely consequences of a behavior." Dari sumber yang kedua ini, diperoleh informasi bahwa keyakinan diri adalah keyakinan terhadap kemampuan yang dimiliki seorang individu untuk belajar atau melakukan keterampilan tertentu.

Dalam proses pembelajaran seorang siswa hendaknya memiliki keyakinan diri yang baik ketika belajar. Hal ini sesuai dengan yang disampaikan Bandura (1999, p.204), "Students with a high sense of efficacy for accomplishing an educational task will participate more readily, work harder, and persist longer when they encounter difficulties than those who doubt their capabilities." Gao, Lee, \& Harrison (2012, p.240) memerkuat pernyataan Bandura dengan mengungkapkan, "In particular, higher self-efficacy would lead to greater persistence and better performance than lower self-efficacy." Dengan demikian, keyakinan diri itu memang seharusnya dimiliki oleh siswa. Dengan keyakinan diri yang tinggi siswa akan memiliki kesempatan lebih besar untuk berhasil dalam proses belajar.

Ada empat hal yang menjadi sumber keyakinan diri. Sebagaimana yang dikatakan Bandura dalam Feltz, Short, \& Sullivan (2008, p.7), He catagorized these sources of information as past performance accomplishments, vicarious experiences, verbal persuasion, and, phycological states.

Selanjutnya, masih dalam sumber yang sama Bandura dalam Feltz, Short, \& Sullivan (2008, p.7) mengatakan bahwa past performance accomplishments adalah yang paling berpengaruh terhadap keyakinan diri. Pernyataan ini diperkuat oleh Haas \& Northam (2010, p.2) yang mengatakan, "Enactive mastery experiences refer to one's personal experiences and are considered the most dependable source of efficacy expectations, serving as indicators of capability." Dengan demikian, dapat disimpulkan bahwa pengalaman seseorang terhadap sebuah capaian akan memengaruhi keyakinan dirinya. Jika seorang individu pernah berhasil dalam melakukan sebuah tugas, maka keyakinan dirinya akan bagus. Demikian pula sebaliknya, jika individu pernah gagal, maka keyakinan dirinya menjadi kecil.

Tingkat keyakinan diri dapat diketahui melalui 3 aspek yang perlu dikembangkan yaitu level, generality, dan strength (Bandura, 1999, p.203). Skala yang disampaikan Bandura tersebut dapat digunakan sebagai acuan untuk membuat kisi-kisi instrumen untuk mengukur keyakinan diri. Adapun kisi-kisi yang dibuat akan menjadi dasar acuan untuk membuat pertanyaan-pertanyaan yang disajikan dalam angket. Angket inilah yang digunakan sebagai instrumen oleh peneliti untuk mengumpulkan data dari sampel yang diteliti.

\section{Hasil Belajar}

"Tinggi rendahnya prestasi belajar tersebut dapat dilihat dari hasil belajar dalam bentuk nilai yang diperoleh", (Hakim, 2005, p.94). Pernyataan Hakim ini mengandung informasi bahwa salah satu bentuk hasil belajar adalah nilai yang diperoleh siswa. Selanjutnya, Rasyid (2009, p.257) memaparkan bahwa ujian pada dasarnya bertujuan untuk mengetahui perkembangan hasil belajar siswa dan hasil mengajar guru. Informasi hasil belajar atau hasil mengajar menunjukkan informasi tentang yang sudah dipahami dan yang belum dipahami oleh sebagian besar siswa. Hasil belajar siswa digunakan untuk memotivasi siswa dan guru agar melakukan perbaikan dan peningkatan kualitas proses pembelajaran. Perbaikan dan peningkatan kualitas proses pembelajaran dilakukan dalam bentuk program remidial dan pengayaan berdasarkan hasil evaluasi hasil ujian. 
Apabila dalam satu tahun waktu tertentu sebagian besar siswa belum mencapai tujuan pembelajaran, maka guru melaksanakan program remidial, sedang bagi siswa yang telah berhasil menguasai diberi program pengayaan. Jadi prinsip dasar mengelola hasil ujian adalah pemanfaatan hasil ujian untuk meningkatkan kualitas pembelajaran.

Rasyid (2009, p.259) menambahkan informasi bahwa ujian diselenggarakan pada akhir pembelajaran untuk mengetahui pen-capaian hasil belajar siswa, dimana dalam format laporan digunakan istilah hasil belajar. Sementara Pradipto (2007, p.119) mengatakan, Kompetensi yang terdapat dalam kurikulum dijabarkan dalam hasil belajar yang dicapai anak setelah melalui kegiatan belajar-mengajar.

Dengan demikian, dapat didefinisikan hasil belajar yang dimaksud dalam penelitian ini adalah hasil ujian yang diselenggarakan di akhir pembelajaran yang bentuknya berupa nilai yang dapat dijadikan indikator keberhasilan pembelajaran yang telah dilaksanakan. Adapun pada kesempatan ini, pembelajaran yang diselenggarakan adalah pembelajaran guling depan. Dengan demikian, hasil belajar yang dimaksud merupakan hasil belajar guling depan. Semakin tinggi nilai yang diperoleh siswa, menunjukkan semakin baik hasil belajar yang ditunjukkan siswa.

Sebagaimana yang sudah dijelaskan pada bagian sebelumnya, bahwa tinggi rendahnya hasil belajar akan menjadi indikator keber-hasilan pembelajaran. Adapun yang melatarbelakangi penentuan hasil belajar siswa dalam pembelajaran diantaranya adalah tujuan umm dari UU Sisdiknas, ketentuan KKM (Kriteria Ketuntasan Minimal), dan kaitannya dengan materi belajar lain.

Sesuai dengan UU Sisdiknas, secara umum tujuan pembelajaran adalah adanya perubahan sikap baik dari segi afektif, kognitif, maupun psikomotor. Kaitannya dengan materi guling depan, maka dalam penelitian ini tujuan pembelajaran dibatasi yaitu untuk membantu siswa supaya dapat melakukan keterampilan guling depan. Selanjutnya menurut KKM dalam silabus pembelajaran, target nilai minimal yang harus dicapai agar siswa dinyatakan menguasi kompetensi adalah 75. Jika dikaitkan dengan materi belajar lainnya, guling depan wajib dikuasai siswa sebagai prasayarat untuk memelajari materi loncat harimau. Siswa yang hendak belajar loncat harimau wajib mengusai teknik guling depan karena teknik guling depan merupakan gerak dasar dari teknik loncat harimau.
Sebagaimana yang telah disampaikan pada bagian sebelumnya, hasil belajar yang diharapkan dapat tercapai pada setiap pembe-lajaran meliputi ranah afektif, psikomotor, dan kognitif. Pada kesempatan ini, hasil belajar lebih ditekankan pada ranah psikomotor dan afektif. Namun demikian, meski bukan menjadi tujuan utama, peningkatan pada ranah kognitif juga diharapkan dapat tercapai.

Dalam penelitian ini, hasil belajar difokuskan pada hasil belajar guling depan. Pada ranah pikomotor, hasil belajar yang ingin dicapai yaitu siswa mempu memraktekkan keterampilan guling depan. Pada ranah afektif peneliti menetapkan sasaran pembelajaran untuk dapat meningkatkan keyakinan diri. Adapun pada ranah kognitif, diharapkan siswa dapat menjelaskan tahap-tahap melakukan teknik guling depan dengan benar. Namun demikian, dengan adanya keterbatasan peneliti, untuk ranah kognitif tidak dilakukan tindakan.

Latihan imagery yang diberikan pada saat pembelajaran diharapkan dapat menghasilkan pembelajaran yang efektif dan efisien. Pembelajaran dikatakan efektif ketika hasil pembelajaran yang diperoleh dapat mencapai target. Adapun target hasil belajar yang diharapkan adalah siswa mendapat nilai minimal sesuai KKM (Kriteria Ketuntasan Minimal), yaitu 75. Efisien yang dimaksud dalam penilitian ini adalah dapat diselenggarakan pembelajaran yang dapat mencapai tujuan dengan waktu sesuai dengan alokasi yang ada pada silabus pembelajaran, yaitu $1 \mathrm{x}$ pertemuan. Pembelajaran yang dimak-sud dalam penelitian ini mencakup penyam-paian materi, latihan keterampilan guling depan, dan penilaian.

Imagery

Weinberg \& Gould (2003, pp.284-285) mengatakan, "Imagery is actually a form of simulation. It is similar to e real sensory experience (e.g., seeing, feeling, or hearing), but the entire experience occurs in the mind." Dengan demikian, dapat kita ketahui bahwa menurut Weinberg \& Gould., imagery itu seperti halnya sebuah simulasi hanya saja simulasi tersebut dilakukan di dalam pikiran. Adapun menurut Fauzee (2003, p.12) imagery merupakan suatu proses dimana informasi yang masuk melalui pancaindra disimpan dalam ingatan, dirasakan secara mendalam, dan kemudian dipraktekkan.

Selanjutnya, Richardson dalam Fauzee (2003, p.12) mengatakan bahwa imagery adalah latihan aktifitas fisik secara simbolik tanpa 
menggerakkan otot. Dengan demikian, dapat diartikan bahwa latihan yang dilakukan hanya terjadi dalam pikiran saja, meski yang dilatih dalam pikiran tersebut adalah aktifitas-aktifitas fisik.

Adapun latihan imagery yang dimaksud dalam penelitian ini adalah proses membayangkan gerakan fisik yang sedang dipelajari dengan mengumpulkan segala bentuk informasi yang pernah diterima menggunakan panca-indera dimana dalam bayangannya seorang individu dapat melakukan gerakan guling depan dengan penuh keyakinan diri dan berhasil mela-kukannya sesuai teknik yang benar.

Weinberg \& Gould (2003, p.291) mengatakan bahwa imagery dapat meningkatkan konsentrasi, mengurangi kecemasan, dan meningkatkan kepercayaan diri. Kaitannya dengan imagery internal dan imagery eksternal, Aziz (2006, p.132) mengatakan bahwa imagery eksternal lebih cocok diterapkan untuk meningkatkan keterampilan sedangkan imagery internal lebih cocok diterapkan untuk meningkatkan aspek mental seorang individu.

Dari pemaparan Gould dan Aziz di atas, dapat diperoleh informasi bahwa imagery memiliki pengaruh terhadap peningkatan keterampilan fisik dan psikologis. Hal ini senada dengan yang diungkapkan Morris, Spittle, \& Watt (2005, p.120), bahwa berbagai penelitian yang mengkaji imagery telah banyak dilakukan. Berbagai penelitian yang telah dilakukan menunjukkan bahwa imagery terbukti berpengaruh terhadap perubahan dalam ranah keterampilan fisik dan segi psikologi yang berdampak pada keterampilan berolahraga.

Selanjutnya, Weinberg \& Gould (2003, p.294) mengatakan, "Probably the best-known use of imagery is for practicing a particular sport skill." Ungkapan Weinberg \& Gould ini menguatkan pernyataan Morris dengan memberikan informasi bahwa imagery bermanfaat dalam proses latihan keterampilan olahraga. Tujuan yang ingin dicapai dengan melakukan latihan imagery diantaranya adalah untuk mengambangkan kepercayaan diri pada atlet, mengembangkan strategi prekompetisi dan kompetisi, membantu atlet memfokuskan perhatian atau konsentrasinya pada suatu bentuk keterampilan tertentu yang sedang dilatihnya, membantu atlet memfokuskan diri pada pertandingan. Istilah atlet disini bukan berarti mengkhususkan latihan imagery dilakukan oleh seseorang yang terampil saja. Selain untuk meningkatkan prestasi, imagery juga dapat diaplikasikan bagi individu yang sedang berlatih keterampilan baru. Berdasarkan teori tersebut peneliti mengaplikasikan latihan imagery pada siswa yang sedang belajar keterampilan guling depan.

Dari berbagai teori tersebut dapat diketahui bahwa fungsi dari latihan imagery adalah untuk meningkatkan keterampilan baik dari segi fisik maupun psikologis. Dari segi psikologis, imagery dapat meningkatkan keyakinan diri. Manfaat latihan imagery yang dapat meningkatkan keterampilan fisik diharapkan dapat menjadikan siswa terampil melakukan guling depan dan memeroleh hasil belajar yang tinggi. Landasan inilah yang melatarbelakangi penulis untuk memilih latihan imagery sebagai metode untuk meningkatkan keyakinan diri dan hasil belajar siswa pada materi guling depan.

Latihan imagery diklasifikasikan menjadi beberapa bentuk, diantaranya adalah cognitive specific, cognitive general, motivational specific, motivational general aurosal, dan motivational general mastery (Komarudin, 2013, p.89). Bentuk latihan imagery dilakukan sesuai dengan tujuan yang hendak dicapai. Komarudin (2013, p.89) mengatakan bahwa latihan imagery yang dilakukan atlet sangat terkait dengan tujuan melakukan latihan imagery, seperti pada kognitif imagery bentuk Cognitive Spesific (CS), digunakan untuk meningkatkan penampilan atlet pada kete-rampilan yang spesifik misalnya hanya untuk meningkatkan motivasi, atau hanya untuk me-ningkatkan kepercayaan diri atlet.

Selanjutnya, Komarudin (2013, p.88) juga menyatakan bahwa imagery bentuk Cognitive Spesific (CS) dilakukan khusus untuk keterampilan olahraga yang spesifik, misalkan tembakan bebas dalam bolabasket. Dengan demikan, diperoleh informasi bahwa untuk meningkatkan keterampilan guling depan dan keyakinan diri dapat dilakukan dengan latihan imagery bentuk Cognitive Spesific (CS).

Latihan imagery memiliki peran dalam usaha seseorang untuk mengusasi keterampilan tertentu. Pernyataan ini didukung oleh Komarudin (2013, p.86) yang memberikan informasi bahwa seorang pegolf bernama Nicklaus melakukan latihan imagery agar dapat memukul bola golf dengan baik. Selanjutnyaa, masih dalam sumber yang sama Komarudin (2013, p.86) menginformasikan, "Nicklaus mengatakan bahwa untuk memukul bola golf yang baik diperlukan 10\% mengayun, $40 \%$ membentuk sikap stance dan setup, dan 50\% membayangkan bagaimana gambaran pola gerak itu terjadi.“ 
Dari yang dikemukakan Komarudin di atas menunjukkan bahwa latihan imagery me-miliki pengaruh yang baik dalam proses belajar keterampilan. Bahkan, dikatakan bahwa imagery menyumbang hingga 50\% untuk keberhasilan seseorang dalam melakukan suatu keterampilan. Hal ini berarti imagery memang sangat bermanfaat dan dapat dilakukan oleh seseorang yang sedang memelajari kete-rampilan tertentu.

\section{Guling Depan}

Nurhayati (2015, p.148) menyatakan bahwa guling depan adalah guling yang dilakukan ke depan. Gerakan guling depan diawali dengan berdiri di atas matras, melakukan guling ke depan di atas matras, dan diakhir guling depan tangan lurus ke depan lalu berdiri, demikian diungkapkan oleh Syarifudin (2014, p.111). Wahyuni (2009, p.134) menerangkan bahwa guling depan dibedakan menjadi dua yaitu guling depan tungkai bengkok dan guling depan tumgkai lurus. Tahap gerakan guling depan tungkai bengkok diawali dengan sikap permulaan jongkok, sedangkan gerakan guling depan tungkai lurus diawali dengan berdiri.

Adapun Adisuyanto (2009, p.79) memberikan penjelasan rangkaian guling depan sebagaimana Gambar 1.

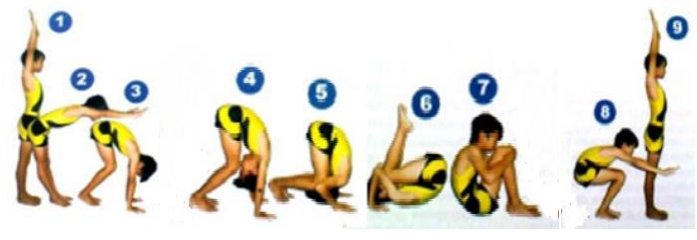

Gambar 1. Rangkaian Gerak Guling Depan (Adisuyanto, 2009, p.79)

\section{METODE}

Desain penelitian tindakan kelas ini mengacu model Kemmis, yang terdiri atas perencanaan, tindakan, pengamatan, dan refleksi (Febrianta \& Sukoco, 2013, p.192). Secara umum, perencanaan dilakukan dengan menyusun RPP, program latihan imagery untuk pembelajaran guling depan, instrumen pengukur tingkat kepercayaan diri siswa (berupa angket), instrumen untuk mengukur keterampilan guling depan siswa, dan pedoman observasi ketercapaian pembelajaran untuk observer. Selanjutnya, tindakan dan pengamatan dilakukan sebagaimana yang sudah direncanakan dalam RPP. Adapun refleksi merupakan kegiatan yang dilakukan oleh peneliti dan observer untuk menganalisis data, menarasikan hasil, dan melakukan evaluasi sebagai dasar merencanakan perbaikan pada siklus selanjutnya.
Penelitian dilaksanakan pada bulan MaretApril 2016. Tindakan tiap siklus dilaksanakan dalam dua pertemuan, disesuaikan dengan jadwal pelajaran penjas yang berlaku. Adapun tempat penilitian dilaksanakan di Madrasah Aliyah Sunan Pandanaran, Jalan Kaliurang Km 12,5 Sleman Yogyakarta.

Subjek dalam penelitian ini adalah Siswa Putri kelas X A MA Sunan Pandanaran yang berjumlah 25 orang. Secara umum karakteristiknya dapat digambarkan sebagai siswa yang orientasi geraknya cukup kecil, keterampilan geraknya kurang jika dibandingkan siswa kelas $\mathrm{X}$ pada umumnya, serta memiliki keyakinan diri yang rendah dalam melakukan gerakan senam lantai khususnya guling depan.

Dalam penelitian ini, penilitian akan diawali dengan melakukan pre-test guling depan terhadap sampel. Setelah pre-test, akan diberikan tindakan, dan terkahir sampel diberikan post-test. Hasil post-test kemudian dianalisis untuk menentukan apakah kriteria keberhasilan sudah tercapai atau belum. Baik pada saat pre-test maupun post-test, yang diukur adalah keyakinan diri dan keterampilan guling depan setiap siswa.

Setetelah melakukan post test, hasil data dianilisis untuk kemudian diinterpretasikan apakan sudah memenuhi kriteria keberhasilan atau belum. Jika hasil belum memenuhi kriteria keberhasilan, maka penelitian dilanjutkan pada siklus kedua. Begitu seterusnya hingga penelitian dapat dihentikan setelah kriteria keberhasilan terpenuhi.

Teknik pengumpulan data dalam penelitian ini melalui angket, tes unjuk kerja, dan observasi. Pengumpulan data melalui angket digunakan untuk mengukur tingkat keyakinan diri yang dimiliki siswa. Instrumen yang digunakan berupa engket penilaian keyakinan diri. Adapun tes unjuk kerja dilakukan untuk mengetahui hasil belajar guling depan siswa. Guru menggunakan instrumen penilaian guling depan dalam melakukan penilaian. Sedangkan observasi dilakukan untuk mengetahui ketercapaian pembelajaran dengan menggunakan instrumen pedoman obsevasi.

Sebelum membuat angket, terlebih dahulu disusun kisi-kisi berkenaan dengan pengukuran keyakinan diri. Adapun kisi-kisi tersebut dikembangkan dari 3 hal utama dalam keyakinan diri yaitu level, generality, dan strenght. Setelah melalui validasi ahli dan uji coba, butir-butir pernyataan pada angket selanjutnya dianalisis validitas dan reliabilitasnya. Hasil analisis vali- 
ditas dan reliabilitas berupa 18 butir pernyataan yang terdistribusi sebagaimana pada Tabel 1 .

Tabel 1. Kisi-Kisi Instrumen Penilaian Keyakinan Diri

\begin{tabular}{cccc}
\hline Variabel & Indikator & Nomor Butir & Jml \\
\hline \multirow{4}{*}{$\begin{array}{c}\text { Level (tingkat } \\
\text { kesulitan) } \\
\text { Keyakinan } \\
\text { Diri }\end{array}$} & $\begin{array}{c}\text { Generality } \\
\text { (keluasan) }\end{array}$ & $1,3,17,7$ & 4 \\
& $\begin{array}{c}\text { Strength } \\
\text { (ketahanan) }\end{array}$ & $10,11,12,9,15$, & 6 \\
& Total & 16,18 & 8 \\
\hline
\end{tabular}

Adapun kisi-kisi instrumen penilaian hasil belajar guling depan dapat dilihat pada Tabel 2 .

Tabel 2. Kisi-Kisi Instrumen Penilaian Hasil Belajar Guling Depan

\begin{tabular}{|c|c|c|c|}
\hline Variabel & Indikator & $\begin{array}{c}\text { Nomor } \\
\text { Butir }\end{array}$ & Jumlah \\
\hline \multirow{5}{*}{$\begin{array}{l}\text { Hasil Belajar } \\
\text { Guling } \\
\text { Depan }\end{array}$} & Sikap Awal & $1,2,3$ & 3 \\
\hline & Pelaksanaan & $4,5,6,7,8$ & 6 \\
\hline & Sikap Akhir & $10,11,12$ & 3 \\
\hline & $\begin{array}{l}\text { Gerakan } \\
\text { Keseluruhan }\end{array}$ & 13,14 & 2 \\
\hline & Total & & 14 \\
\hline
\end{tabular}

Analisis data dalam penelitian ini dilakukan secara kualitatif dan kuantitatif. Teknik analisis data secara kualitatif dilakukan dengan cara peneliti bersama observer merefleksi hasil observasi terhadap proses pembelajaran yang dilaksanakan guru dan siswa di lapangan.

Adapun analisis data secara kuantitatif dilakukan pada data keyakinan diri dan hasil belajar guling depan. Keyakinan diri diperoleh datanya menggunakan angket yang berisi 18 butir pernyataan. Setiap pernyataan memiliki skor antara 1-4, dengan demikian skor maksimal yang dapat diperoleh adalah 72. Selanjutnya skor tersebut akan diubah menjadi nilai dengan skala 100 dengan cara,

$$
\text { skor }=\frac{\text { jumlah skor yang diperoleh }}{72} \times 100
$$

Skor yang diperoleh kemudian dikonversikan menjadi huruf. Sebagaimana ketentuan penilaian pada pembelajaran, maka penilaian keyakinan diri akan dilakukan menggunakan format abjad sebagaimana yang ada pada Tabel 3. Dari Tabel 3 dapat diperoleh informasi bahwa siswa minimal harus mendapatkan skor 75 untuk bisa mendapatkan nilai B dan dinyatakan lulus KKM.
Tabel 3. Kriteria Penilaian Keyakinan Diri

\begin{tabular}{ccc}
\hline No. & Skor & Nilai \\
\hline 1. & $88-100$ & $\mathrm{~A}$ \\
2. & $75-87$ & $\mathrm{~B}$ \\
3. & $63-74$ & $\mathrm{C}$ \\
4. & $<63$ & $\mathrm{D}$ \\
\hline
\end{tabular}

Selanjutnya, penentuan konversi pada penilaian hasil belajar guling depan diperoleh berdasarkan perhitungan:

Skor $=\frac{\text { jumlah skor yang diperoleh }}{14} \times 100$

Dikarenakan tidak semua hasil berupa bilangan bulat, maka hasil konversi dibulatkan sebagaimana yang ada pada Tabel 4 .

Selanjutnya, analisis data secara kuantitatif juga dilakukan pada hasil belajar guling depan. Berdasarkan landasan teori yang sudah disampaikan pada bagian awal, maka peneliti membuat rubrik penilaian keterampilan guling depan dengan aspek yang dinilai ada 14 poin. Dengan demikian, maka skor maksimal yang dapat diperoleh adalah 14. Data yang diperoleh kemudian dianalisis dengan diubah menjadi nilai. Berdasarkan peraturan penilaian ranah psikomotor, maka data yang diperoleh akan diubah menjadi nilai dalam bentuk angka dengan skala 0-100. Adapaun kriteria penilannya dapat dilihat pada tabel 3. Dari tabel 3 dapat disimpulkan bahwa minimal skor yang harus diperoleh untuk bisa KKM adalah 11 (dengan nilai 79).

Tabel 4. Kriteria Penilaian Hasil Belajar Guling Depan

\begin{tabular}{ccc}
\hline No. & Skor & Nilai \\
\hline 1. & 14 & 100 \\
2. & 13 & 93 \\
3. & 12 & 86 \\
4. & 11 & 79 \\
5. & 10 & 71 \\
6. & 9 & 64 \\
7. & 8 & 57 \\
8. & 7 & 50 \\
9. & 6 & 43 \\
10. & 5 & 36 \\
11. & 4 & 29 \\
12. & 3 & 21 \\
13. & 2 & 14 \\
14. & 1 & 7 \\
15. & 0 & 0 \\
\hline
\end{tabular}

\section{HASIL DAN PEMBAHASAN}

\section{Hasil}

Pada bagian ini akan ditampilkan data yang menunjukkan adanya peningkatan keyakinan diri dan hasil belajar guling depan melalui 
latihan imagery yang diintegrasikan ke dalam pembelajaran penjasorkes.

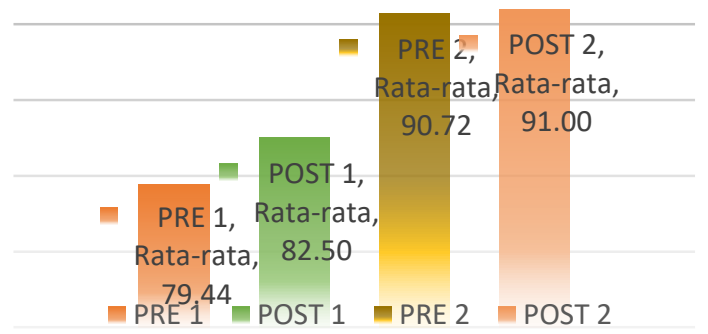

Gambar 2. Grafik Peningkatan Tingkat Keyakinan Diri pada Siklus 1 dan Siklus 2

Gambar 2 adalah grafik yang menunjukkan terjadinya pengingkatan keyakinan diri selama dilakukannya tindakan. Selanjutnya, pada tabel 5 akan ditampilkan data yang menunjukkan adanya peningkatan hasil belajar yang diperoleh siswa dalam belajar guling depan malalui latihan imagery.

Tabel 5. Distribusi Data Hasil Belajar Guling Depan pada Siklus 1 dan Siklus 2

\begin{tabular}{ccccc}
\hline Keterangan & Pre 1 & Post 1 & Pre 2 & Post 2 \\
\hline KKM & 1 & 14 & 13 & 25 \\
Belum KKM & 24 & 11 & 12 & 0 \\
$0-25$ & 6 & 1 & 0 & 0 \\
$26-50$ & 18 & 4 & 3 & 0 \\
$51-75$ & 0 & 6 & 9 & 0 \\
$75-100$ & 1 & 14 & 13 & 25 \\
min & 0 & 21 & 29 & 79 \\
max & 86 & 100 & 100 & 100 \\
Rata-rata & 35,43 & 71,43 & 74,57 & 90,00 \\
\hline
\end{tabular}

Data hasil penelitian menunjukkan peningkatan terjadi pada aspek keyakinan diri yang dimiliki siswa. Hal ini merupakan hal yang wajar disamping karena manfaat yang diperoleh dari latihan imagery, keyakinan diri yang dimiliki siswa juga meningkat karena prestasi siswa melakukan guling depan juga meningkat. Sebagaimana yang dikatakan Bandura dalam Feltz, Short, \& Sullivan (2008, p.7) bahwa past performance accomplishments adalah yang paling berpengaruh terhadap keyakinan diri. Pernyataan ini diperkuat oleh Haas \& Northam (2010, p.2) yang mengatakan, Enactive mastery experiences refer to one's personal experiences and are considered the most dependable source of efficacy expectations, serving as indicators of capability."

Dari kedua pernyataan ini dapat disimpulkan bahwa pengalaman seseorang terhadap sebuah capaian akan memengaruhi keyakinan dirinya. Jika seorang individu pernah berhasil dalam melakukan sebuah tugas, maka keyakinan dirinya akan bagus. Kesimpulan ini diperkuat oleh Jackson (2010, p.68) yang menyatakan bahwa keyakinan diri dan latihan memiliki hubungan timbal balik. Meskipun keyakinan adalah faktor penentu seseorang dalam melakukan latihan, latihan juga merupakan sumber dari keyakinan diri. Hal ini terlihat pada hasil skala angket keyakinan diri setelah tindakan pada siklus 2 . Tingkat keyakinan diri setelah tindakan dilaksanakan pada siklus 2 menunjukkan hasil yang baik. Peningkatan keyakinan diri pada siswa dapat dilihat pada Gambar 2.

Belum terpenuhinya kriteria keberhasilan pada siklus 1 melatarbelakangi penelitian untuk dilanjutkan pada siklus 2. Pada siklus 1, diketahui bahwa hasil belajar keterampilan guling depan belum mampu memenuhi kriteria keberhasilan. Dari data yang ada dapat diperoleh informasi bahwa sebelas siswa belum mencapai KKM. Sebelas anak yang belum KKM masing-masing mendapatkan nilai 21, 29, 29, 36, 43, 64, 64, 64, 71, 71, dan 71. Kriteria keberhasilan tindakan untuk hasil belajar keterampilan guling depan adalah siswa yang mencapai KKM yaitu 75 minimal $75 \%$ dari jumlah total siswa dalam satu kelas. Total siswa dalam satu kelas adalah 25, maka kriteria ketuntasan adalah jumlah siswa yang mencapai KKM minimal 18 orang (dari hasil hitung 18,75).

Setelah dilakukan refleksi dan perbaikan, hasil dari tindakan pada siklus 2 menunjukkan bahwa integrasi latihan imagery pada pembelajaran guling depan dapat meningkatkan hasil belajar siswa dalam praktek guling depan. Data peningkatan hasil belajar guling depan melalui integrasi latihan imagery dapat dibuktikan pada Tabel 4. Hasil belajar pada post test siklus kedua menunjukkan hasil belajar semua siswa sudah mencapai KKM. Hal ini mengindikasikan bahwa berdasarkan hasil belajar keterampilan guling depan yang diperoleh setelah dilakukan tindakan, penelitian telah memenuhi kriteria keberhasilan dan layak untuk dihentikan. Berdasarkan latar belakang ini, peneliti tidak melanjutkan penelitian pada siklus selanjutnya.

\section{Pembahasan}

Pada siklus pertama, siswa terlihat belum benar-benar memahami latihan imagery. Pembelajaran dengan integrasi latihan imagery merupakan hal baru bagi siswa dan baru pertama kali dilakukannya. Berkenaan dengan hal ini, kolaborator memberikan informasi bahwa siswa terlihat bingung ketika guru menyampaikan bahwa siswa 
akan melakukan latihan imagery pada pembelajaran guling depan. Rendahnya pemahaman siswa tentang imagery menyebabkan siswa tidak memahami fungsi latihan imagery sehingga tidak dapat memanfaatkan latihan imagery dengan maksimal.

Kendala lain yang ada pada siklus pertama adalah motivasi belajar guling depan siswa yang rendah. Informasi ini diperoleh dari pernyataan kolaborator yang menyatakan bahwa beberapa siswa tidak antusias untuk memraktekkan guling depan. Para siswa terlihat hanya duduk sambil melihat siswa yang lain melakukan guling depan. Namun kejadian ini sedikit berkurang pada pertemuan kedua. Kemungkinan pada pertemuan kedua siswa lebih aktif dan bersemangat berlatih karena pada pertemuan kedua akan diselenggarakan penilaian.

Dari segi fasilitas yang digunakan, dalam pembelajaran matras yang digunakan berjumlah 2 buah. Hal ini ternyata menjadi kendala karena pada saat melakukan praktek guling depan, antrian cukup panjang. Hal ini menyebabkan waktu banyak terbuang sia-sia. Ditambah lagi beberapa siswa tampakragu-ragu untuk melakukan guling depan yang terlihat dari sikapnya yang berulang kali menjauh dari matras kemudian mendekat lagi sebelum akhirnya melakukan guling depan. Sikap siswa ini tentu saja semakin memperlambat antrian. Kejadian ini secara tidak langsung memperkecil kesempatan siswa untuk memraktekkan guling depan.

Hasil observasi juga memberikan informasi bahwa banyak siswa yang mengeluh karena kesulitan memraktekan gerakan berdiri di akhir gerakan guling depan. Dari hasil diskusi dengan siswa dan pengamatan oleh guru dan kolaborator menghasilkan informasi bahwa bentuk matras yang tebal menyulitkan anak untuk segera berdiri setelah berguling. Selain itu, kendala lain dalam pembelajaran adalah banyak siswa yang tidak memahami kesalahan yang dilakukan. Siswa kesulitan untuk menganalisis gerakannya sendiri yang secara tidak langsung menyebabkan siswa kesulitan untuk melakukan perbaikan terhadap gerakannya.

Dari hasil kegiatan refleksi pada siklus 1 yang sudah disajikan, guru bersama dengan kolaborator menyusun perencanaan untuk perbaikan. Perencanaan yang disusun selanjutnya dilakukan pada tindakan di siklus 2. Pada Tabel 6 akan disajikan data hasil refleksi siklus 1 dan perbaikan yang dilakukan pada siklus 2 .

Tabel 6. Hasil Refleksi Siklus 1 dan Perbaikan yang Dilakukan Pada Siklus 2

\begin{tabular}{|c|c|c|}
\hline No. & $\begin{array}{c}\text { Hasil Refleksi Siklus } 1 \\
\end{array}$ & Perbaikan Yang Dilakukan Pada Siklus 2 \\
\hline 1. & $\begin{array}{l}\text { Matras hanya } 2 \text { buah, antri terlalu panjang, } \\
\text { siswa memiliki kesempatan yang kecil untuk } \\
\text { praktek guling depan. }\end{array}$ & $\begin{array}{l}\text { Menambah } 2 \text { buah kasur busa dan } 1 \text { set karpet pazle } \\
\text { sehingga total ada } 5 \text { matras yang dapat digunakan. }\end{array}$ \\
\hline 2. & $\begin{array}{l}\text { Matras yang terlalu tebal menyulitkan anak } \\
\text { untuk segera berdiri setelah melakukan } \\
\text { gerakan guling depan. }\end{array}$ & $\begin{array}{l}\text { Menambah } 2 \text { buah kasur busa dan } 1 \text { set karpet pazle } \\
\text { yang ukurannya lebih tipis dari matras yang } \\
\text { digunakan pada siklus } 1 .\end{array}$ \\
\hline 3. & $\begin{array}{l}\text { Beberapa siswa hanya duduk melihat teman } \\
\text { yang lain praktek karena malas mengantri. }\end{array}$ & $\begin{array}{l}\text { Guru menegur siswa yang hanya duduk melihat siswa } \\
\text { lain praktek guling depan dan memerintahkannya } \\
\text { untuk memanfaatkan matras yang ada untuk berlatih. }\end{array}$ \\
\hline 4. & $\begin{array}{l}\text { Pemahaman siswa tentang latihan imagery } \\
\text { rendah. Saat pembelajaran siswa saling } \\
\text { bertanya pada teman yang lain tentang latihan } \\
\text { imagery. Penjelasn guru tentang latihan } \\
\text { imagery belum cukup memuaskan siswa. }\end{array}$ & $\begin{array}{l}\text { Dengan pemutaran video dan penjelasan yang lebih } \\
\text { banyak tentang latihan imagery membuat siswa } \\
\text { semakin paham betapa penting dan bermanfaatnya } \\
\text { latihan imagery. }\end{array}$ \\
\hline 5. & $\begin{array}{l}\text { Motivasi siswa rendah dalam belajar guling } \\
\text { depan. }\end{array}$ & $\begin{array}{l}\text { Guru menjelaskan bahwa siswa harus menguasai } \\
\text { gerakan guling depan sebagai gerakan dasar untuk } \\
\text { berlatih dan menguasai gerakan-gerakan lain yang } \\
\text { lebih sulit. }\end{array}$ \\
\hline 6. & $\begin{array}{l}\text { Siswa masih menunjukkan rassa takut untuk } \\
\text { melakukan guling depan. }\end{array}$ & $\begin{array}{l}\text { Guru mewajibkan siswa untuk melakukan imagery } \\
\text { sebelum praktek guling depan, agar memiliki } \\
\text { keyakinan diri yang lebih tinggi. }\end{array}$ \\
\hline 7. & $\begin{array}{l}\text { Siswa kesulitan menganilis kesalahan dan } \\
\text { melakukan perbaikan. }\end{array}$ & $\begin{array}{l}\text { Guru memperbolehkan siswa untuk melihat kembali } \\
\text { video model maupun video rekaman gerakan yang } \\
\text { pernah dilakukan dan mendampingi siswa dalam } \\
\text { menganalisis gerakan yang salah serta membantu } \\
\text { siswa melakukan perbaikan. }\end{array}$ \\
\hline
\end{tabular}


Dari Tabel 6 diperoleh informasi bahwa setelah dilakukan observasi dan dari hasil refleksi, selanjutnyadisusun rencana tindakan yang akan dilakukan pada siklus 2. Berdasarkan hasil pengamatan di lapangan, dari hasil perbaikan yang dilakukan menunjukkan pembelajaran pada siklus 2 berjalan lebih efektif dengan adanya tambahan matras. Ditambah lagi dengan tindakan guru menegur siswa yang hanya duduk melihat siswa lain praktek guling depan memotivasi siswa untuk lebih aktif dan berungguh-sungguh berlatih guling depan.

Setelah mengetahui bahwa motivasi siswa rendah dalam belajar guling depan, guru berusaha meyakinkan siswa bahwa gerakan guling depan harus dikuasai sebagai gerakan dasar untuk berlatih dan menguasai gerakan-gerakan lain yang lebih sulit. Penjelasan yang diberikan guru kepada siswa menumbuhkan kesadaran dalam diri siswa. Kesadaran yang dimiliki siswa akan dibutuhkannya penguasaan guling depan sebagai gerakan dasar untuk berlatih dan menguasai gerakan-gerakan lain membuat siswa semakin termotivasi untuk berlatih. Selanjutnya, kebijakan guru dengan memberikan kesempatan kepada siswa untuk melihat video model dan video rekaman sesuai kebutuhan memudahkan siswa dalam melakukan perbaikan atas gerakan-gerakan yang masih salah.

Proses ini dikenal sebagai belajar observasional yang digagas oleh Bandura. Siswa mengalami proses antensi, retensi, produksi, dan motivasi (Hergenhahn \& Olson, 2008: 367). Setelah melihat video model, siswa memiliki pengetahuan tentang gerakan guling depan yang benar. Ketika melihat videonya sendiri, siswa mengetahui bagian-bagian mana yang masih belum sesuai dan membutuhkan perbaikan. Proses melihat video baik video model merupakan proses atensional. Kegiatan siswa dalam menyimpan informasi penting dalam usaha melakukan keterampilan yang benar merupakan proses retensi. Informasi ini yang selanjutnya akan dimunculkan oleh siswa ketika diperlukan. Taktek, Zinsser, \& St-John (2008, p.174) dalam penelitiannya menyimpulkan bahwa fungsi imagery adalah pada proses retensi. Selanjutnya, Stewart (2006) menambahkan informasi bahwa melalui Mental Imagery dan Video Modelling dapat meningkatkan pemahaman dan selanjutnya terbentuk retensi memori pada individu yang sedang mempelajari keterampilan tertentu yang diperlukan untuk memperoleh keterampilan motorik.
Setelah siswa memiliki retensi tentang gerakan guling depan yang baik, selaunjutnya siswa berusaha melakukan gerakan guling depan sesuai dengan pemahaman yang diperolehnya. Proses ini oleh Bandura disebut sebagai proses produksi. Ketika siswa mampu melakukan guling depan dengan baik, ditambah dengan penguatan yang diberikan oleh lingkungan, maka akan terjadi proses motivasional. Pada proses ini siswa akan termotivasi untuk melakukan gerakan guling depan yang baik, sebagaimana pemahaman yang dimilikinya sesuai dengan gerakan yang ada pada video model.

Kebijakan guru untuk memberikan kesempatan lebih banyak kepada siswa untuk melihat video model dan video rekaman merupakan tindakan yang tepat. Hal ini didukung oleh Taylor \& Wilson (2005: 11) dengan menyatakan, "Because past behavior is the strongest predictor of current self-efficacy judgements, by observing oneself executing successful moves, a learner pays greater attention and provided with the information to continue progressing." Taylor \& Wilson (2005: 11) menambahkan informasi bahwa peningkatan keyakinan diri juga terjadi pada pemain hoki yang melakukan self-modellingyang juga berdampak pada peningkatan akurasinya dalam melakukan tembakan. Hal ini diperkuat oleh Bandura (1977) dalam Murray \& Noland (2013: 51) yang mengungkapkan, “... modelling is powerful way to learn and refine skills."

Selanjutnya, dengan pemutaran video dan penjelasan yang lebih banyak mengenai latihan imagery membuat siswa semakin paham betapa penting dan bermanfaatnya latihan imagery. Kondisi ini menjadikan siswa lebih bersungguhsungguh dalam melakukan latihan imagery. Kondisi ini serupa dengan hasil penelitian dari Silbernagel, Short, \& Ross-Stewart (2007: 1081), "Athletes found imagery to be more effective if they had previous training in imagery. This finding was not found for imagery use, though. This means that athletes use imagery whether they have had formal training or not. However, it is considered to be more effective by those who have some experience with it." Silbernagel dalam penelitiannya menemukan kondisi bahwa atlet yang memiliki pengalaman terhadap imagery akan lebih efektif melakukan latihan imagery dari pada atlet lain yang kurang berpengalaman.

Tindakan guru untuk mewajibkan siswa melakukan imagery sebelum praktek guling depan menjadikan siswa terbiasa melakukan imagery sebelum guling depan. Kebiasaan ini 
membuat siswa semakin tinggi keyakinan dirinya dalam melakukan guling depan dan menunjukkan gerakan yang bagus. Dengan munculnya kebiasaan ini menunjukkan bahwa siswa juga telah mampu melakukan latihan imagery sendiri setelah sebelumnya dipandu oleh guru.

Dari pelaksanaan tindakan pada siklus 2 dapat diketahui bahwa setelah dilakukan perbaikan, pembelajaran pada siklus 2 menjadi lebih baik. Siswa menunjukkan sikap yang lebih bersemangat dan lebih aktif untuk belajarguling depan sehingga proses belajar menunjukkan guru tidak lagi menjadi pusat belajar. Hasil tindakan pada siklus 2 menunjukkan pembelajaran dengan mengintegrasikan imagery menjadi lebih efektif setelah siswa memahami fungsi dan manfaat imagery.

Latihan imagery yang dilakukan siswa bermanfaat untuk menambah keyakinan diri dalam diri siswa. Hal ini nampak pada perubahan yang terjadi selama pembelajaran. Pada awal pembelajaran guru sering memotivasi siswa dalam melakukan praktek guling depan, namun tindakan guru semakin jarang dilakukan seiring dengan sikap siswa yang dengan penuh keyakinan diri melakukan guling depan.Selain itu, beberapa siswa terlihat membantu siswa lain untuk menganalisis gerakan yang dilakukannya serta memberikan masukan atas kesalahan yang dilakukan. Tindakan siswa ini menunjukkan bahwa siswa sudah memahami gerakan guling depan dengan baik.

Siswa yang bisa menilai gerakan guling depan siswa lain menandakan bahwa dia telah menguasai guling depan dengan baik. Hal ini diperkuat oleh pernyataan Pizzera (2012, p 603), “... that judges use their personal experiences as information to accurately assess complex gymnastic." Kesimpulan Pizzera diperoleh dari penelitian yang dilakukannya mengenai kemampuan juri senam dalam melakukan penilaian. Pizzera meneliti dua kelompok juri yang terdiri dari juri yang terampil melakukan gerakan dan juri yang tidak terampil melakukan gerakan yang dinilainya. Hasil penelitan memberikan informasi bahwa juri yang terampil dapat menilai lebih baik terhadap gerakan yang dinilainya.

\section{SIMPULAN}

Integrasi latihan imagery dalam pembelajaran penjasorkes dapat meningkatkan keyakinan diri pada siswa putri kelas X Madrasah Aliyah Sunan Pandanaran. Adapun peningkatan yang terjadi pada aspek keyakinan diri dapat diketahui dari peningkatan rata-rata skor kelas pada pre- test dan post-test siklus 1 adalah 79,44 menjadi 82,50 . Sedangkan peningkatan pada pre test dan post-test siklus 2 adalah 90,72 menjadi 91,00. Adapun prosentase peningkatan keyakinan diri mulai dari siklus 1 hingga sikul 2 adalah 68\%, $92 \%, 92 \%$, dan $100 \%$.

Integrasi latihan imagery dalam pembelajaran penjasorkes dapat meningkatkan hasil belajar guling depan pada siswa putri kelas $\mathrm{X}$ Madrasah Aliyah Sunan Pandanaran. Peningkatan hasil belajar guling depan nampak pada hasil analisis rata-rata nilai kelas pada empat penilaian pre test dan post test siklus 1 yaitu 35,43 menjadi 71,43 . Pada siklus 2 rata-rata penigkatan hasil belajar guling depan terjadi dari 74,57 menjadi 90,00 . Adapun prosentase peningkatan hasil belajar guling depan mulai dari siklus pertama dan kedua adalah 4\%, 56\%, 52\%, dan 100\%.

Setiap guru hendaknya inovatif dalam menghadapi permasalahan yang terjadi di kelas. Dengan usaha yang maksimal, proses pembelajaran akan berlangsung maksimal pula. Dengan demikian, tujuan pendidikan akan memiliki kemungkinan yang lebih besar untuk dapat tercapai. Integrasi latihan imagery dapat dilakukan pada materi lain sebagai bentuk inovasi pembelajaran untuk mencapai tujuan pempelajaran.

Penelitian-penelitian yang bertujuan untuk meningkatkan kualitas pembelajaran sangat diperlukan untuk kemajuan pendidikan Indonesia. Dengan penelitian yang dilakukan, dapat diperoleh informasi ilmiah mengenai solusi dari kendala-kendala yang terjadi selama pembelajaran

\section{DAFTAR PUSTAKA}

Ay, K. M., Halawaweh, R. S., Al-Taieb, M. A. (2013). The effect of movement imagery training on learning forearm pass in volleyball. ProQuest, 134, 227-239.

Aziz, S. A. (2006). Mengaplikasi teori psikologi dalam sukan. Kuala Lumpur: Yeohprinco.

Bandura, A. (1999). Self-efficacy in changing societies. New York, NY: Cambridge University Press.

Destani, F. (2011). Relationships among the physical education climate and physical activity in junior high school physical education: a mediational analysis. (Disertasi doktor, The University of Utah, 2011). University Microfilms International, 3468222, 235. 
Fauzee, M. S. O. (2003). Penyelesaian masalah atlet melalui pendekatan psikologi. Selangor: Lohprint SDN.

Febrianta, Y. \& Sukoco, P. (2013). Upaya peningkatan pembelajaran permainan bolabasket melalui metode pendekatan taktik siswa SMPN 2 Pandak Bantul. Jurnal Keolahragaan, 1 (2), 186-196. doi:http://dx.doi.org/10.21831/jk.v1i2.257 4.

Feltz, D. L., Short, S. E., \& Sullivan, P. J. (2008). Slef-eficacy in sport. Illinois: Human Kinetics.

Gao, Z., Lee, A.M., \& Harrison L.,Jr. (2012). Understanding students' motivation in sport and physical education: from the expectancy-value model and self-efficacy theory perspectives. Quest, 60:2, 236-254.

Giacobbi, P. R., Tuccitto, D. E., \& Buman M. P., et al. (2010). Measurement and conceptual investigation of exercise imagery establishing construct validity. Research Quarterly for Exercise and Sport, 81, 485493.

Haas, B., K., \& Northam, S. (2010). Measuring self-efficacy: development of the physical activity assessment inventory. Southern Online Journal of Nursing, 10, 1-18. Retrieved from SOJNR: http://www.resourcenter.net/images/snrs/f iles/sojnr_articles2/vol10num04art03.htm 1

Hakim, T. (2005). Belajar secara efektif. Jakarta: Pustaka Pembangunan Swadaya Nusantara.

Hergenhahn, B., R., \& Olson, M., H. (2008). Theoris of learning (7th ed.). Jakarta: Kencana.

Jackson, D. (2010). How personal trainers can use self-efficacy theory to enhance exercise behavior in beginning exercisers. Strength and Conditioning Journal, 32, 67-71.

Komarudin. (2013). Psikologi olahraga. Bandung: Remaja Rosdakarya.

McAuley, M. (1985). Modeling and selfefficacy: a test of bandura's model. Journal of Sport Psychology, 7, 283-295.

Menteri Negara Pemuda dan Olahraga. (2008). Cerdas dan bugar dengan senam lantai. Jakarta: Grasindo.
Morris, T., Spittle, M., \& Watt, A. P. (2005). Imagery in sport. Illinois: Human Kinetics.

Murray, S., \& Noland, B. (2013 ). Video modelling for young children with autism spectrum disorders. London: Jessica Kingsley Publisher.

Nurhayati, S. (2015). Sekali baca langsung inget ulangan harian dan semesteran SD kelas 3. Jakarta: Niaga Swadaya.

Pizzera, A. (2012). Gymnastic Judges Benefit From Their Own Motor Experience as Gymnasts. Research Quarterly for Exercise and Sport, 83, 603-607.

Pradipto, Y. D. (2007). Belajar sejati versus kurikulum nasional. Yogyakarta: Kanisius.

Rasyid, H. (2009). Penilaian hasil belajar. Bandung: CV Wacana Prima.

Republik Indonesia. (2003). Undang-Undang Republik Indonesia Nomor 20 Tahun 2003, tentang Sistem Pendidikan Nasional.

Silbernagel, M. S., Short, S. E., \& Ross-Stewart, L. C. (2007). Athletes' use of exercise imagery during weight. Journal of Strength and Conditioning Research, 21, 1077-1081.

Stewart, S. M. (2006). The effects of mental imagery, video modeling, and physical practice on the rate of acquisition of a new figure skating skill (Tesis master, University of Alberta, 2006). MAI 44/05, 96.

Syarifudin. (2014). Pendidikan jasmani, olahraga, dan kesehatan untuk SMA/MA/SMK/MAK kelas X. Jakarta: Kementrian Pendidikan dan Kebudayaan.

Taktek, K., Zinsser, N., \& St-John, B. (2008). Visual versus kinesthetic mental imagery: Efficacy for the retention and transfer of a closed motor skill in young children. Canadian Journal of Experimental Psychology, 62, 174-187.

Taylor, J., \& Wilson, G. (2005). Applying sport psychology. Human Kinetics: Illionis.

Wahyuni, S. (2009). Pendidikan jasmani, olahraga dan kesehatan 1 untuk kelas $X$ SMA dan MA. Solo: Tiga Serangkai.

Weinberg , R. S. \& Gould, D. (2003). Foundations of sport \& exercise psychologi. Illinois: Human Kinetics. 
Jurnal Keolahragaan 6 (1), 2018 - 99

Rizki Sito Harimurti

Zimmerman, B. J. (2000). Self-efficacy: an essential motive to learn. Contemporary Educational Psychology, 25, 82-91.

Zimmerman, B. J., Bandura, A., \& Martinez-

Pons, M. (1992). Self-motivation for academic attainment: the role of selfefficacy beliefs and personal goal setting. American Educational Research Journal, 29, 663-676. 